\title{
Highlight report: prediction of drug induced liver injury (DILI) with human hepatocytes in vitro
}

\author{
Wiebke Albrecht ${ }^{1}$
}

Received: 21 November 2017 / Accepted: 22 November 2017 / Published online: 27 November 2017

c) Springer-Verlag GmbH Germany, part of Springer Nature 2017

Recently, William Proctor and colleagues have published a comprehensive study about the use human hepatocyte spheroids to predict DILI in patients (Proctor et al. 2017). This is a highly relevant topic, since DILI remains a major challenge in toxicology (Godoy et al. 2013; Björnsson 2015; Dragovic et al. 2016; Ghallab 2014). One of the conclusions of the authors is that three-dimensional human hepatocyte spheroid cultures allowed a higher sensitivity compared to human hepatocytes that were simply cultivated on collagen coated dishes (Proctor et al. 2017). However, this is not surprising, since similar observations have been reported in the past (Hewitt et al. 2007; Hengstler et al. 2000; Deharde et al. 2016; Luckert et al. 2017; Rebelo et al. 2015). However, the set of data presented by the authors is of high relevance. They report cytotoxicity of human hepatocyte spheroids concentration-dependently incubated with 110 drugs for 14 days. These drugs have been categorized into: (1) severe clinical DILI concern, (2) high clinical DILI concern, (3) low clinical DILI concern, (4) enzyme elevations in the clinic, (5) no DILI concern. Moreover, the maximal plasma concentrations $\left(C_{\max }\right)$ of these drugs have been reported. Using the DILI severity category and exposure-corrected cytotoxicity, the authors report that hepatocyte spheroids can be used for classifying hepatotoxicants from different pharmacological classes (Proctor et al. 2017).

Particularly relevant conclusions can be drawn from the electronic supplemental material. In Proctor et al. 2017, the Supplementary table S-3 cytotoxicity data $\left(\mathrm{IC}_{50}\right)$ and the human plasma peak concentrations $\left(C_{\max }\right)$ have been summarized (Table S-3, S3 hLiMT data). For some compounds the in vitro $\mathrm{IC}_{50}$ and plasma peak concentrations are in the same order of magnitude. For example the category 1

Wiebke Albrecht

albrecht@ifado.de

1 IfADo-Leibniz Research Centre for Working Environment and Human Factors at TU Dortmund, Ardeystr. 67, 44139 Dortmund, Germany (severe DILI concern) compound ketoconazole has an $\mathrm{IC}_{50}$ of $4.6 \mu \mathrm{M}$ and a $C_{\max }$ of $11.3 \mu \mathrm{M}$. This results in a ratio $\left(\mathrm{IC}_{50} / C_{\max }\right)$ of 0.4 , also named 'margin of safety' (MOS). Therefore, the in vitro system with hepatocyte spheroids predicts the in vivo situation for ketoconazole quite well. However, the situation is difficult for other compounds with severe DILI concern (category 1): ximelagatran shows an in vitro $\mathrm{IC}_{50}$ of $150 \mu \mathrm{M}$, but the human plasma peak concentration $\left(C_{\max }\right)$ is only $0.45 \mu \mathrm{M}$. Therefore, the risk of human DILI has been massively underestimated by the in vitro system. Similar problems exist for the category 1 compounds dantrolene, methotrexate, stavudine and trovafloxacin (Proctor et al. 2017; Table S-3, S3h LiMT data). It is interesting to note that cytotoxicity allows a good prediction of human blood concentrations associated with an increased risk of DILI for some compounds, while it leads to a massive underestimation of other severe DILI compounds.

In recent years, much effort has been invested into the development of hepatocyte in vitro systems (Ehrhardt and Schmicke 2016; Ramboer et al. 2015; Verhulst et al. 2015; Hammad and Ahmed 2014; Hammad et al. 2017; Godoy et al. 2016, 2015; Grinberg et al. 2014). Besides cytotoxicity further readouts, such as gene expression or functional endpoints have been recommended (Grinberg et al. 2014; Reif et al. 2015; Rashidi et al. 2016; Arbo et al. 2016). However, a comprehensive study including a sufficiently large number of compounds for validation of these endpoints is not yet available. The merit of the present study (Proctor et al. 2017) is that it delivers a comprehensive cytotoxicity database, which clearly demonstrates that cytotoxicity alone is not sufficient to predict human DILI. In conclusion, the hunt for an accurate in vitro system quantitatively predicting human hepatotoxicity has only just begun. 


\section{References}

Arbo MD, Melega S, Stöber R et al (2016) Hepatotoxicity of piperazine designer drugs: up-regulation of key enzymes of cholesterol and lipid biosynthesis. Arch Toxicol 90(12):3045-3060

Björnsson ES (2015) Drug-induced liver injury: an overview over the most critical compounds. Arch Toxicol 89(3):327-334. https:// doi.org/10.1007/s00204-015-1456-2. Review

Deharde D, Schneider C, Hiller T et al (2016) Bile canaliculi formation and biliary transport in 3D sandwich-cultured hepatocytes in dependence of the extracellular matrix composition. Arch Toxicol 90(10):2497-2511

Dragovic S, Vermeulen NP, Gerets HH et al (2016) Evidence-based selection of training compounds for use in the mechanism-based integrated prediction of drug-induced liver injury in man. Arch Toxicol 90(12):2979-3003 Review.

Ehrhardt S, Schmicke M (2016) Isolation and cultivation of adult primary bovine hepatocytes from abattoir derived liver. EXCLI J 15:858-866. https://doi.org/10.17179/excli2016-794

Ghallab A (2014) The rediscovery of HepG2 cells for prediction of drug induced liver injury (DILI). EXCLI J 13:1286-1288

Godoy P, Hewitt NJ, Albrecht U et al. (2013) Recent advances in 2D and $3 \mathrm{D}$ in vitro systems using primary hepatocytes, alternative hepatocyte sources and non-parenchymal liver cells and their use in investigating mechanisms of hepatotoxicity, cell signaling and ADME. Arch Toxicol 87(8):1315-1530. https://doi.org/10.1007/ s00204-013-1078-5. Review

Godoy P, Schmidt-Heck W, Natarajan K et al (2015) Gene networks and transcription factor motifs defining the differentiation of stem cells into hepatocyte-like cells. J Hepatol 63(4):934-942. https:// doi.org/10.1016/j.jhep.2015.05.013. Erratum in: J Hepatol. 2016 Feb;64(2):525-526

Godoy P, Widera A, Schmidt-Heck W et al (2016) Gene network activity in cultivated primary hepatocytes is highly similar to diseased mammalian liver tissue. Arch Toxicol 90(10):2513-2529. https:// doi.org/10.1007/s00204-016-1761-4

Grinberg M, Stöber RM, Edlund K et al (2014) Toxicogenomics directory of chemically exposed human hepatocytes. Arch Toxicol 88(12):2261-2287. https://doi.org/10.1007/s00204-014-1400-x

Hammad S, Ahmed H (2014) Biomarker: the universe of chemically induced gene expression alterations in human hepatocyte. EXCLI J 13:1275-1277 No abstract available
Hammad S, Adel-Wareth AAA, El-Sayed YS (2017) In vitro-in vivo correlation: Hepatotoxicity testings. J Exp Appl Animal Sci, [S.1.], v. 1, n. 3, p. 384-387, mar. 2016. ISSN 2314-5692. Available at: http://www.m-sciences.com/index.php?journal=jeaas\&page $=$ arti cle\&op=view\&path\%5B \%5D=1066.Date accessed: 18 nov. 2017. https://doi.org/10.20454/jeaas.2015.1066

Hengstler JG, Utesch D, Steinberg P et al (2000) Cryopreserved primary hepatocytes as a constantly available in vitro model for the evaluation of human and animal drug metabolism and enzyme induction. Drug Metab Rev 2000 Feb 32(1):81-118

Hewitt NJ, Lechón MJ, Houston JB et al (2007) Primary hepatocytes: current understanding of the regulation of metabolic enzymes and transporter proteins, and pharmaceutical practice for the use of hepatocytes in metabolism, enzyme induction, transporter, clearance, and hepatotoxicity studies. Drug Metab Rev 39(1):159-234 Review

Luckert C, Schulz C, Lehmann N et al (2017) Comparative analysis of 3D culture methods on human HepG2 cells. Arch Toxicol 91(1):393-406

Proctor WR, Foster AJ, Vogt J et al (2017) Utility of spherical human liver microtissues for prediction of clinical drug-induced liver injury. Arch Toxicol 91(8):2849-2863. https://doi.org/10.1007/ s00204-017-2002-1

Ramboer E, Rogiers V, Vanhaecke T, Vinken M (2015) Effects of Trichostatin A on drug uptake transporters in primary rat hepatocyte cultures. EXCLI J 14: 567-576. https://doi.org/10.17179/ excli2015-220

Rashidi H, Alhaque S, Szkolnicka D, Flint O, Hay DC (2016) Fluid shear stress modulation of hepatocyte-like cell function. Arch Toxicol 90(7):1757-1761. https://doi.org/10.1007/s00204-016-1689-8

Rebelo SP, Costa R, Estrada M, Shevchenko V, Brito C, Alves PM (2015) HepaRG microencapsulated spheroids in DMSO-free culture: novel culturing approaches for enhanced xenobiotic and biosynthetic metabolism. Arch Toxicol 89(8):1347-1358. https:// doi.org/10.1007/s00204-014-1320-9

Reif R, Karlsson J, Günther G et al (2015) Bile canalicular dynamics in hepatocyte sandwich cultures. Arch Toxicol 89(10):1861-1870. https://doi.org/10.1007/s00204-015-1575-9

Verhulst S, Best J, van Grunsven LA, Dollé L (2015) Advances in hepatic stem/progenitor cell biology. EXCLI J 14:33-47. https:// doi.org/10.17179/excli2014-576 Review. 